\title{
Tardy male anorexia nervosa ultimately responded to ECT
}

Ahmed Naguy ${ }^{1 *}$ and Ali Al-Tajali ${ }^{2}$

*Correspondence: ahmednagy@hotmail.co.uk

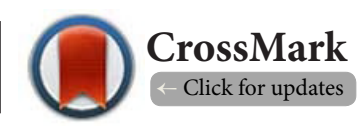

'Psychiatrist, Kuwait Centre for Mental Health (KCMH), Kuwait.

${ }^{2}$ General Adult Psychiatrist, Head of Neuromodulation Unit, $\mathrm{KCMH}$, Kuwait.

\section{Correspondence}

Anorexia Nervosa (AN) is one of the few 'real' psychiatric emergencies [1], with $10-15 \%$ mortality rate; $2 / 3$ due to medical complications and $1 / 3$ due to suicidality. Crow et al., reported a crude mortality rate of $4 \%$ [2]. Incidence of $0.5 \%$, female outnumbers male by a ratio of 10:1. AN is commonly thought of as a female disorder. Even though as much as $25 \%$ of the clinical population is male, research on AN in males is limited [3]. It is defined clinically with marked distortion of body image, pathologic desire for thinness, and self-induced weight loss with body mass index (BMI) of 17.5 or less. Mean age of onset is 16-17 years for females and 12 years for males [4]. A combined approach is recommended for management of AN; pharmacologic (best evidence for fluoxetine and olanzapine), psychologic (family therapy and cognitive-behavioural therapy CBT) and bibliotherapy [5]. Pharmacotherapy is generally of limited value especially acutely but might help with relapse prevention. Hospitalization is indicated in presence of serious medical sequelae [6]. Male gender and late onset ("tardy AN") generally portend poor prognostication $[7,8]$. Electroconvulsive therapy (ECT) in recalcitrant AN is supported by few case reports in the literature [9].

A 42-year-old Kuwaiti gentleman was referred to us from a private facility in accompaniment of his wife, with a diagnosis of AN-restricting subtype that failed a 3 months trail of fluoxetine $\left(\right.$ Prozac $^{\circledR}$ ) $20 \mathrm{mg}$ and cyproheptadine $\left(\right.$ Periactin $^{\circledR}$ ) $8 \mathrm{mg} / \mathrm{d}$. He was also engaged in 12 sessions of weekly high-quality CBT. Extensive workup was contemplated including laboratory investigations, electrolyte panel, thyroid function (TFT), B12 and folate, toxicologic (UTox) screen, electrocardiography (ECG), electroencephalography (EEG), magnetic-resonance imaging (MRI) Brain with gadolinium (Gd) enhancement and rheumatologic profile. Hypochromic microcytic anaemia, mild hypokalaemia, sinus bradycardia and a pattern of "pseudoatrophy" [10] were noted. Anthropometry was accomplished as well as Quetlet formula showing BMI of 17. Patient has obvious longitudinal anankastic personality traits ('anal character') as reported by his wife with the characteristic triad of obstinacy, parsimony and pedantism. Elaborative psychometry entailed Ideal Body Stereotype Scale-Revised, Perceived Sociocultural Pressure Scale, Eating Disorder Diagnostic Scale, Yale-Brown obsessive-compulsive scale (Y-BOCS), Beck's depression inventory (BDI), Minnesota mutiphasic personality inventory-2 (MMPI-2) and Brown assessment of beliefs scale (BABS). Patient was partially insighted, with no depressive overlay or frank psychosis. We pushed fluoxetine to $40 \mathrm{mg} / \mathrm{d}$ and introduced olanzapine $\left(Z y p r e x a^{\circledR}\right) 10 \mathrm{mg} / \mathrm{d}$ in lieu of cyproheptadine. After 4 weeks, the course was relentlessly deteriorating and the patient was losing much weight (BMI dropped to 16) and totally refusing food. He was hospitalized for intravenous (IV) drips and correction of concomitant dyselectrolaemia. He was pallid, sallow and gaunt, albeit, very resistive and disengaging. He refused to pursue with psychotropic medications. He endorsed no suicidality but was ostensibly demoralized and in marked distress. We opted for ECT on emergency basis. After 3 sessions of bitemporal modified ECT, he began to be more brightened, engaging, serene, less preoccupied, and, above all compliant with meds which then changed to fluoxetine $60 \mathrm{mg} / \mathrm{d}$ and quetiapine (Seroquel XR ) $300 \mathrm{mg} / \mathrm{d}$. We continued to a totality of 6 sessions. No cognitive side-effects were reported. CBT was reinstituted. Patient was discharged and followed up in OPD. After 2, 4, 8 and 12 weeks, he kept exponentially improving, put on $4 \mathrm{kgs}$, and faring well both socially and vocationally. Although he is still 'obsessed' with 'ideal' body weight, he is maintained on a well-balanced diet with our nutritionist, attending weekly CBT sessions and treatment-adherent.

We opine that ECT remains a viable option to explore in cases of severe AN, especially in life-threatening conditions even in the absence of comorbid depression as this case illustrates.

We theorize that efficacy of ECT in AN could be ascribed to presumed 'anti-obsessional' actions [11], independent of its antidepressant actions. Moreover, it is postulated that ECT acutely increases NE activity and endogenous opiates [12], and this could rectify the replicated findings of deficits in MHPG (methoxyhydroxyphenylglycol) and endogenous opiates activity in AN [13]. 
Naguy et al. Journal of Psychiatry and Brain Functions 2015,

http://www.hoajonline.com/journals/pdf/2055-3447-2-1.pdf

List of abberivations

ECT: Electroconvulsive therapy

AN: Anorexia Nervosa

CBT: Cognitive-behavioural therapy

Competing interests

The author declares that he has no competing interests.

Authors' contributions

\begin{tabular}{|l|c|c|}
\hline Authors' contributions & AN & AAT \\
\hline Research concept and design & $\checkmark$ & -- \\
\hline Collection and/or assembly of data & $\checkmark$ & -- \\
\hline Data analysis and interpretation & -- & -- \\
\hline Writing the article & $\checkmark$ & $\checkmark$ \\
\hline Critical revision of the article & -- & $\checkmark$ \\
\hline Final approval of article & -- & $\checkmark$ \\
\hline Statistical analysis & -- & -- \\
\hline
\end{tabular}

Acknowledgement

Authors wish to express their deep gratitude to

Dr. Haya Al-Mutairi, Director General of KCMH for

supervising the clinical work all through.

Publication history

Senior Editor: Gianluca Serafini, Sapienza University of Rome, Italy. Editor: Emilio Gutierrez Garcia, University of Santiago de Compostela, Spain.

Received: 18-May-2015 Final Revised: 26-Jun-2015

Accepted: 28-Jun-2015 Published: 06-Jul-2015

\section{References}

1. Johnson AS and Hillard JR. Prevalence of eating disorders in the psychiatric emergency room. Psychosomatics. 1990; 31:337-41. | Article I PubMed

2. Crow SJ, Peterson CB, Swanson SA, Raymond NC, Specker S, Eckert ED and Mitchell JE. Increased mortality in bulimia nervosa and other eating disorders. Am J Psychiatry. 2009; 166:1342-6. | Article | PubMed

3. Wooldridge $T$ and Lytle PP. An overview of anorexia nervosa in males. Eat Disord. 2012; 20:368-78. | Article | PubMed

4. Campbell $\mathrm{K}$ and Peebles R. Eating disorders in children and adolescents: state of the art review. Pediatrics. 2014; 134:582-92. I Article I PubMed

5. Lock J and La Via MC. AACAP Committee on Quality Issues. Practice parameters for the assessment and treatment of children and adolescents with eating disorders. J Am Acad Child Adolesc Psychiatry. 2015; 54:412-25.

6. Mehler PS, Krantz MJ and Sachs KV. Treatments of medical complications of anorexia nervosa and bulimia nervosa. J Eat Disord. 2015; 3:15. | Article I PubMed Abstract | PubMed Full Text

7. Coelho JS, Kumar A, Kilvert M, Kunkel L and Lam PY. Male Youth With Eating Disorders: Clinical and Medical Characteristics of a Sample of Inpatients. Eat Disord. 2015; 1-7. I Article I PubMed

8. Luca A, Luca M and Calandra C. Eating Disorders in Late-life. Aging Dis. 2015; 6:48-55. | Article | PubMed Abstract | PubMed Full Text

9. Ferguson JM. The use of electroconvulsive therapy in patients with intractable anorexia nervosa. Int J Eating Diord. 1993; 13:195-201.

10. Sein P, Searson S, Nicol AR and Hall K. Anorexia nervosa and pseudoatrophy of the brain. Br J Psychiatry. 1981; 139:257-8. | PubMed

11. Tomruk NB, Saatcioglu O, Ugurlu E et al. ECT Use in Refractory Obsessive-Compulsive disorder. Bulletin of Clinical Psychopharmacology. 2010; 20:2.

12. Fosse R and Read J. Electroconvulsive Treatment: Hypotheses about Mechanisms of Action. Front Psychiatry. 2013; 4:94. | Article I PubMed Abstract I PubMed Full Text
13. Kaye WH, Wierenga CE, Bailer UF, Simmons AN and Bischoff-Grethe A Nothing tastes as good as skinny feels: the neurobiology of anorexia nervosa. Trends Neurosci. 2013; 36:110-20. | Article | PubMed Abstract I PubMed Full Text

\section{Citation:}

Naguy A and Al-Tajali A. Tardy male anorexia nervosa ultimately responded to ECT. J Psychiatry Brain Funct. 2015; 2:1.

http://dx.doi.org/10.7243/2055-3447-2-1 